\title{
Submarine evidence of glacier surges
}

\section{ANDERS SOLHEIM}

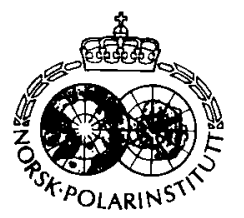

\section{The Bråsvellbreen area}

Surges constitute a common form of glacier advance on the Svalbard archipelago (Liestøl 1969), northwestern Barents Sea. The Austfonna ice cap $\left(8100 \mathrm{~km}^{2}\right)$ covers most of Nordaustlandet, the second largest island in the archipelago (Fig. 1). It has its entire southern and eastern front grounded in the sea under open, marine conditions. Between 1937 and 1938 the Bråsvellbreen glacier, which is part of the Austfonna ice cap, had a major surge which is well documented from aerial photography (Hoel \& Werenskiold 1962: 73-74; Schytt 1969). Since 1938, the glacier has retreated several kilometres.
It was expected that such a surge, most likely advancing over unconsolidated glacial and glaciomarine sediments, would leave a distinct imprint on the sea floor.

During marine geological and geophysical cruises in 1982 and 1983, high frequency acoustical profiling was conducted in the area just outside Bråsvellbreen (Solheim \& Pfirman 1985). $3.5 \mathrm{kHz}$ echo sounder, $1 \mathrm{~kJ}$ sparker and $50 \mathrm{kHz}$ side scan sonar records indeed showed a marked difference between the area that was covered by the surge (the surge zone) and the area outside. The most important morphological features can be summarized as follows (Solheim \& Pfirman 1985):

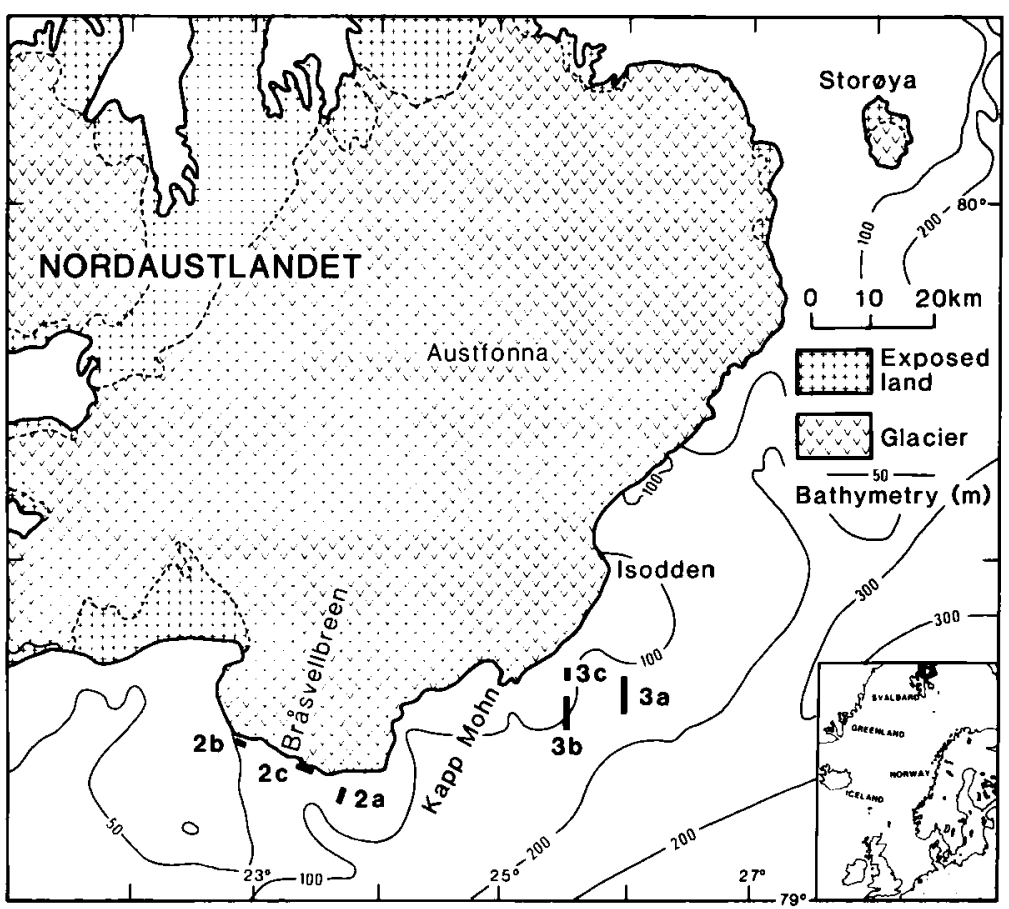

Fig. I. Nordaustlandet with the Austfonna ice cap and the study areas. Heavy lines with numbers refer to figures later in the text. 
- A continuous ridge, subparalleling the glacier front at a distance of $500 \mathrm{~m}$ to $>5 \mathrm{~km}$ (Fig. 2a). Ridge relief varies between $8 \mathrm{~m}$ and $20 \mathrm{~m}$ and width between $500 \mathrm{~m}$ and $1700 \mathrm{~m}$. This is considered to be the end moraine defining the maximum extension of the surge. The ridge is partly pushed up, but a large part of it was probably deposited from meltwater during and shortly after the surge, giving rise to the transparent, lense-like character of the distal parts. Slump features give further indications of rapidly deposited and unstable sediment configuration in this part of the ridge.

- A more or less rhombohedral pattern of linear, discontinuous ridges between the end moraine and the present glacier front (Fig. 2b). These ridges have a relief of about $5 \mathrm{~m}$ and spacing in the order of $20-50 \mathrm{~m}$. This is interpreted as crevasse fill through a squeeze-up process, and as such it reflects the relief in the glacier sole during the surge. The pattern is most likely preserved through stagnation of the glacier after surge. The two main ridge directions defining the rhombohedral pattern furthermore coincide with the crevasse pattern on the glacier surface during the surge.

- Singular sediment mounds. Most likely, these have a similar origin as the ridges.

- Small, discontinuous arcuate ridges, subparallel to the glacier front (Fig. 2c). These are most likely caused by minor, local movements, possibly annual winter advances that commenced after the stagnant glacier snout had disintegrated through calving and the glacier healed after the surge.

Concerning the ridges forming the rhombohedral pattern. it should be mentioned that similar features, recently reported from Iceland, also have been interpreted as crevasse fill under a surging glacier (Sharp, in press).

\section{The Kapp Mohn-Isodden area}

From the general appearance of the southeastern coast of Nordaustlandet (Fig. 1) it may be expected that the area between Kapp Mohn and Isodden also has its protruding shape from surge activity.

Another indication of surge in this area is given by Nordenskiöld (1874:95) in his description of a sledge expedition across Nordaustlandet in 1873.
From an area approximately $40 \mathrm{~km}$ northwest of Kapp Mohn, Nordenskiöld describes intensely crevassed ice which forced the expedition members off their route. Further towards Kapp Mohn the glacier descended to a lower plain, bounded by a terraced escarpment to the south and covered by large blocks of ice.

Furthermore, a recent paper (Dowdeswell et al. 1986) presents a detailed map of bedrock structure under the ice cap. This work clearly shows a topographic depression underlying Brăsvellbreen, and an even better expressed valley leading out to the area between Kapp Mohn and Isodden. According to Dowdeswell (1984), surface profiles are below equilibrium, and calculated driving stresses low in both areas, indicating that both are in a stagnant phase between surges.

During a hydrographic cruise in the area south of Kapp Mohn in 1984, the same acoustical equipment as previously described was used in a number of north-south running profiles. Approaching the glacier, a similar pattern to that described from Bråsvellbreen was encountered. From a relatively smooth, ice-ploughed sea floor, the profiles pass over a sediment lense (Fig. 3a \& b) into a strikingly different morphology, with a more irregular relief. In this area a rhombohedral ridge pattern of approximately the same scale as that in front of Bråsvellbreen is recognized (Fig. 3c), as well as singular sediment mounds. The sediment lense does not have as distinct a ridge character as does the Bråsvellbreen end moraine. However, it clearly resembles the distal part of the Bråsvellbreen ridge, with its low-angle slope, relatively transparent acoustic character, and rather abrupt termination.

No subparallel ridges indicating recent annual glacier oscillations were recorded, but the survey only covered a small part of the area in front of the supposed surge-front, and all profiles ended at a distance of $400-500 \mathrm{~m}$ from the glacier.

\section{Conclusions}

The new data from the area south of Kapp Mohn lead to the following conclusions:

- An ice stream of the the Austfonna ice cap had a major surge in 1873 . The surging ice may have extended $15-20 \mathrm{~km}$ out into open, marine conditions and thus was comparable in size to the 65 years younger Bråsvellbreen surge. 
a)
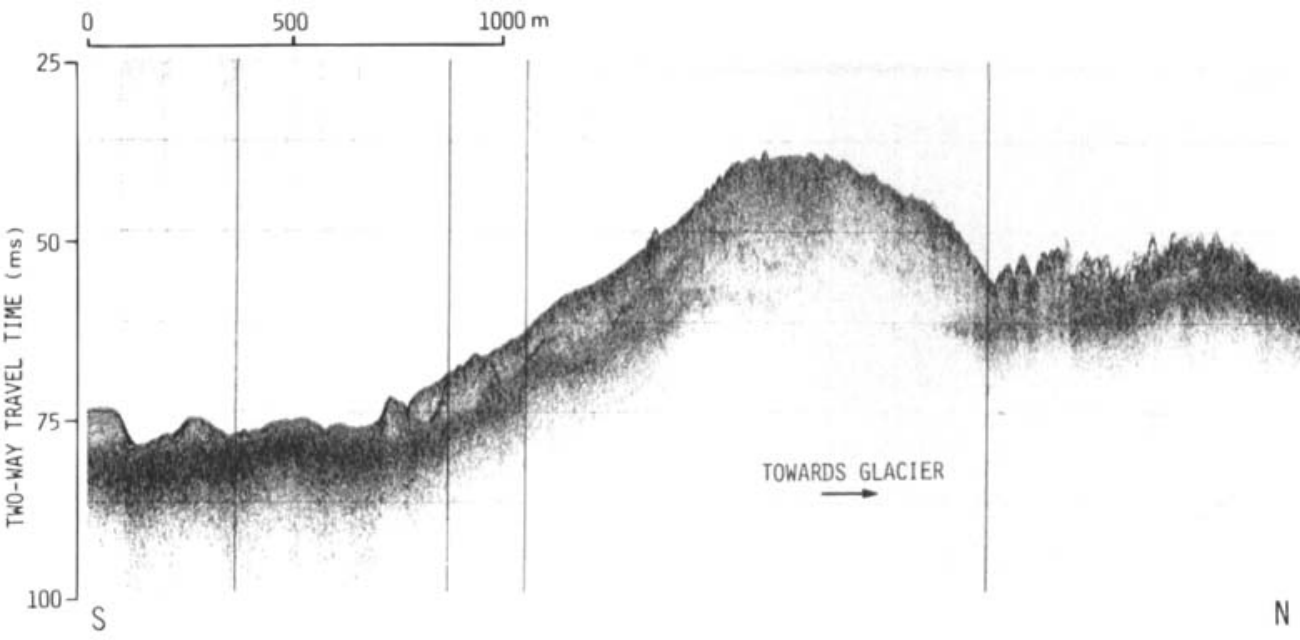

b)

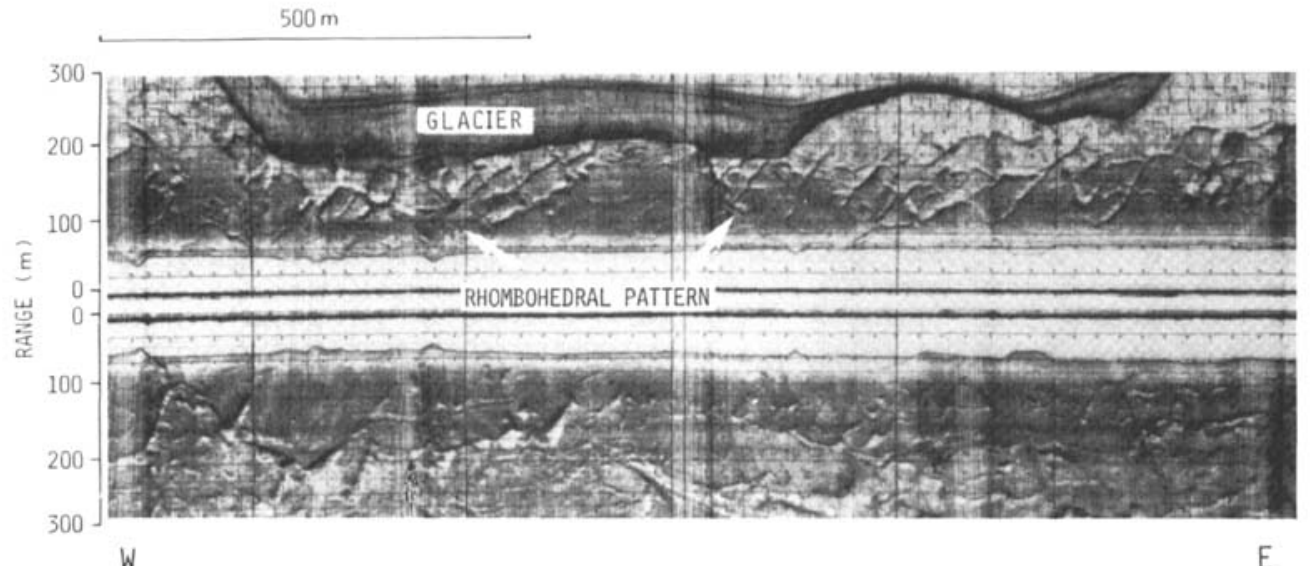

c)

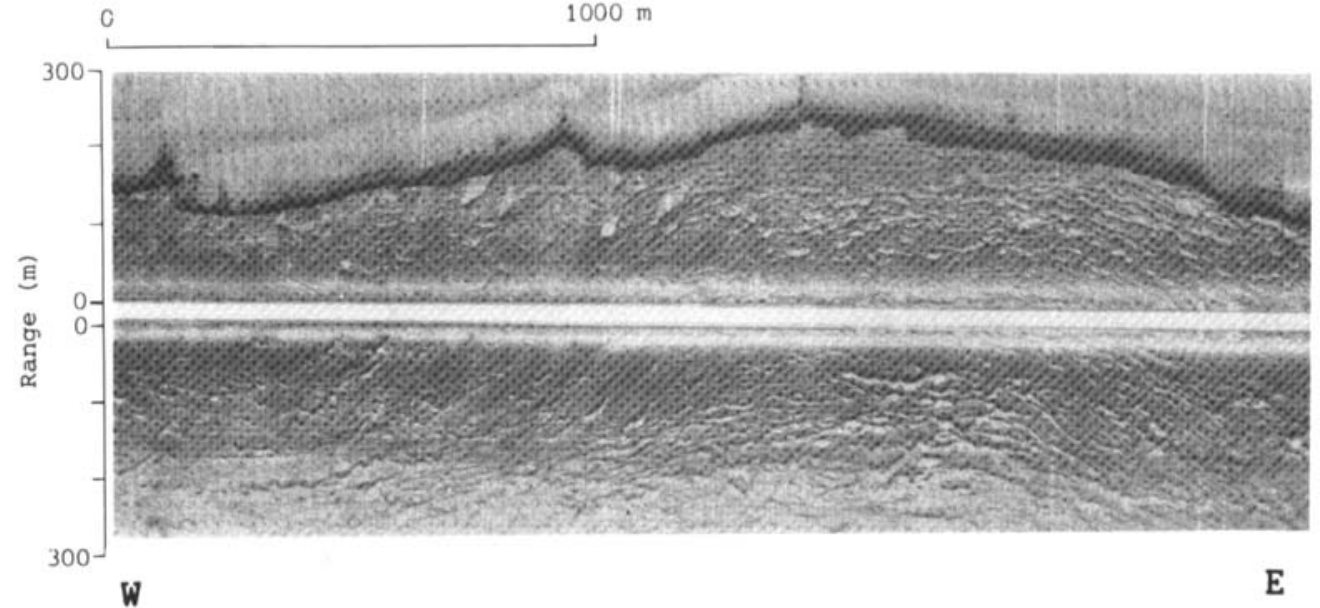

Fig. 2. Morphologic features outside Bråsvellbreen (from Solheim \& Pfirman 1985): (a) $3.5 \mathrm{kHz}$ record across the end moraine. (b) Side scan sonograph along the glacier front, showing the rhombohedral ridge pattern. (c) Side scan sonograph along the glacier front. showing the parallel ridges. 

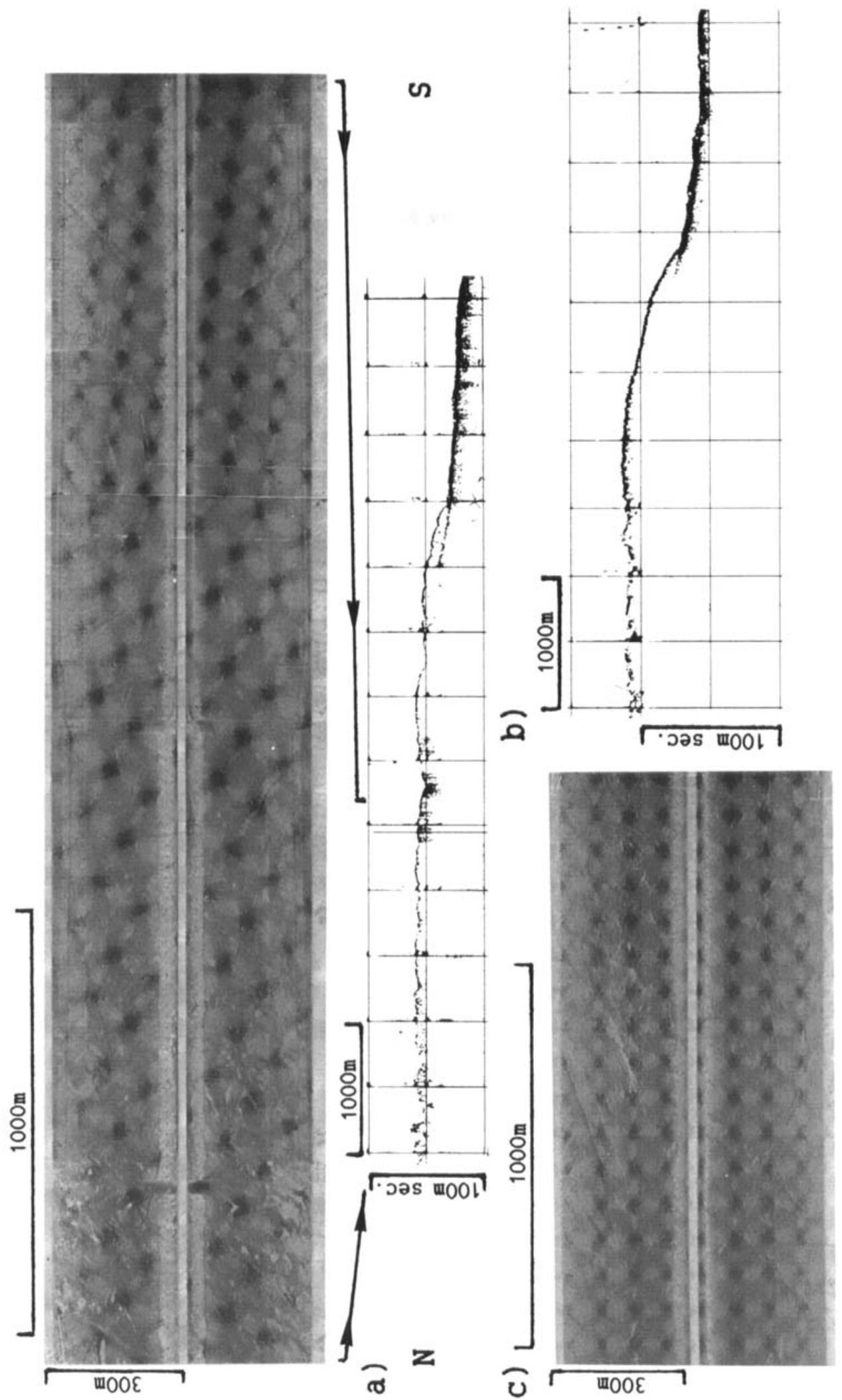

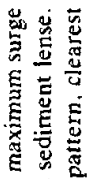

폴 줄

흥

要

范范

政

을.

总品

동

通

능

ह 등

은

들

言品

공 영

몰

정

E

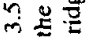

롱

结

运电总

定宽

등

品

政

嘫

手

政

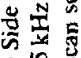

成

政

氜

害喜完

둥

15

동

要

通荡

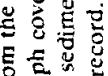

施焉

象题

品

至吉壳

可语

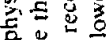

总定焉

$\dot{m} \dot{v}=$

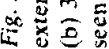


- Glacier surges with grounded marine extensions advancing over unconsolidated sediment leave a distinct suite of sea floor morphologic features. This morphology is preserved through stagnation of the glacier which then disintegrates by calving.

- A broad ridge or sediment lense marks the maximum surge extent. The morphology changes distinctly across this accumulation. On the outside, the sea floor is only disturbed by ordinary iceberg gouging, while inside, in the surge zone, the sea floor reflects the shape of the glacier sole during the surge. Sediment mounds and ridges forming a rhombohedral pattern are characteristic. These are formed by crevasse filling through a squeeze-up process and reflect the fracture pattern in the surging glacier.

- If the glacier at a later stage resumes normal activity, small ridges formed by annual oscillations may overprint the surge pattern.

Acknowledgements. - The cruise in 1984 was conducted by the Norwegian Hydrographic Survey (NSKV). We are grateful to NSKV for their cooperative spirit and willingness to reduce ship speed for seismic profiling. Olav Trygve Egderød participated for Norsk Polarinstitutt and is acknowledged for successfully carrying out the ficld operation. Captain Terje Langvik and the crew of R/V LANCE are all acknowledged for their valuable field assistance. Sparker equipment was borrowed from the Norwegian Defense Research Establishment (FFI).

\section{References}

Dowdeswell, J. A. 1984: Remote sensing studies of Svalbard glaciers. Unpubl. Ph. D. thesis, University of Cambridge. 250 pp.

Dowdeswell, J. A., Drewry, D. J., Cooper, A. P. R., Gorman, M. R., Liestøl, O. \& Orheim, O. 1986: Digital mapping of the Nordaustlandet ice caps from airborne geophysical investigations. Ann. Glaciol. 8 (in press).

Hoel, A. \& Werenskiold, W. 1962: Glaciers and snowfields in Norway. Nor. Polarinst. Skr. 114, 291 pp.

Liestøl, O. 1969: Glacier surges in West Spitsbergen. Can. J. Earth Sci. 6, 895-987.

Nordenskiöld, A. E. 1874: Redogörelse før den svenska polarexpeditionen, år 1872-1873. Bihang till K. Suenska Vet. Akad. Handlingar 2(18), $132 \mathrm{pp.}$

Schytt. V. 1969: Some comments on glacier surges in eastern Svalbard. Can. J. Earth Sci. 6, 867-871.

Sharp, M. 1985: Crevasse-fill ridges - A landform type characteristic of surging glaciers. Geografiska Annaler 67A, 213220.

Solheim, A. \& Pfirman, S. L. 1985: Sea-floor morphology outside a grounded, surging glacier; Bråsvellbreen. Svalbard. Marine Geology 65, 127-143. 